\title{
UNCOVERING MOSES BEN SABBATAI: A FOURTEENTH-CENTURY CRITIC OF PHILOSOPHERS AND KABBALISTS*
}

\author{
ELLEN DE DONCKER \\ UC LOUVAIN
}

In his monograph, Moïs b. Sabbatai, lecteur juif du Livre des causes et adversaire de la Kabbale, en Italie, vers 1340, Jean-Pierre Rothschild introduces an important Jewish philosopher and the writings attributed to this medieval scholar. ${ }^{1}$ Through his intensive research and earlier studies, Rothschild has single-handedly saved Moses ben Sabbatai from oblivion. ${ }^{2}$ Rothschild now carefully presents the thinker, his writings, and his sources, providing the most extensive material for studies on Moses b. Sabbatail. Rothschild's book also constitutes the main source for information on the Hebrew reception of the Liber de causis.

Rothschild's careful and extremely well-researched study consists of seven parts. In the introduction (p. 1-44), which contains four subsections, Rothschild first introduces the broad context of Moses b. Sabbatai. He presents the main ideas of the philosophical and Jewish intellectual climate in thirteenth- and fourteenth-century Italy. Special attention is paid to the Jewish reception of the

This work was supported by the Fonds de la Recherche Scientifique - FNRS.

1 JeAn-PIERRE Rothschild, Moise b. Sabbatai, lecteur juif du Livre des causes et adversaire de la Kabbale, en Italie, vers 1340, Brepols, Turnhout 2018 (Philosophy in the Abrahamic Traditions of the Middle Ages, 2).

2 See, for instance, JeAn-PIERRE Rothschild, «En quel sens on peut parler de 'mystique philsophique' dans la philosophie juive du moyen âge occidental », in PAUL B. FENTION, Roland GOETSCHEL (eds.), Expérience mystique, écriture mystique et philosophie mystique dans le judaïsme et les religions du Livre, Brill, Leiden 2000 (Études sur le judaïsme médiéval, 22), p. 113-129. See also JEAN-PIERRE ROTHSCHILD, « Le Livre des causes du latin à l'hébreu: textes, problèmes, réception », in AleXANder Fidora, Harvey J. HAmes, Yossef Schwartz (eds), Latin-into-Hebrew: Texts and Studies, vol. II, Brill, Leiden 2013 (Studies in Jewish History and Culture, 40), p. 47-84 (esp. p. 80-81).
\end{abstract}


Liber de causis, pointing to a 'Jewish philosophical school' consisting of important scholars such as Zerahiyāh b. Se'altiēl Ḥēn, Hillel of Verona, Juda of Rome, and perhaps his cousin Emmanuel of Rome. This 'school' shares interests in Neoplatonic themes and Latin scholasticism, and a strong devotion to Maimonides and «une veritable 'foi' en la possibilité de l'union de l'intellect possible (ou humain) avec l'Intellect Agent » (p. 5). The Jewish reception of the Liber de causis seems to bridge the two main currents of Jewish thinking in Italy during the thirteenth and fourteenth centuries, providing a response to both the Kabbalists and the rationalist philosophers. Rothschild introduces Moses b. Sabbatai within this intellectual current, discovering him only through small marginal notes in a manuscript of Juda of Rome. He presents possible, but uncertain, biographical elements and offers the (probable) context and main ideas of the writings that have been attributed to this thinker. At the end of the introduction, Rothschild carefully presents the justifications of his study, paying attention to the specific style of Moses's writings.

In the subsequent three parts, Rothschild proposes a critical translation together with extremely detailed notes and helpful introductions - of the works attributed to Moses b. Sabbatai. First, the reader finds the Explication of Psalm 119:126 (p. 45-90), prefaced with a general presentation, then an annotated translation, followed by a critical edition of the Hebrew text. Secondly, the Ša'arēy ședeq ('Gates of Justice') is offered (p. 91-226), again, with an introductory sketch, an annotated translation, and then a critical edition of the Hebrew text. Thirdly, the Scripta Minora are presented (p. 227-252). These minor writings contain four texts: notes to Sefer ben porat of Juda of Rome; notes to Juda of Rome's translation of Thomas Aquinas's commentary on the Liber de Causis; Moses's poem Šir 'eden ha-hayyim ('Song of the Eden of the living'); and a note on the degrees of existence. After this extensive study of writings attributed to Moses b. Sabbataï, Rothschild inserts five rich appendices that offer useful tools for the study of the main works of Moses (p. 253-310). The first four appendices present Moses's most important sources (Juda of Rome's Hebrew translation of the Liber de causis, the Prologues of Juda of Rome's translation of Liber de causis, quotes from Giles of Rome's De esse et essentia used by Moses, and a note of Juda of Rome on Thomas Aquinas's commentary of the Liber de causis). The fifth appendix offers a glossary made by Rothschild, cataloging the philosophical terms used by Moses. The book ends with a bibliography, followed by indices of passages, names, manuscripts, and philosophical terms.

\section{Moses b. Sabbatai}

The biographical details of Moses b. Sabbatai are entirely unknown to us. Some chronological indices, found in writings which can most probably be attributed to Moses, situate our philosopher around the year 1340 (p. 19). Moreover, it is 
most likely that Moses was a disciple of Juda of Rome, or at least one of his attentive readers, and thus was part of a 'cult' of Maimonidean followers in Rome at that time. ${ }^{3}$ Moses depends largely on Juda of Rome for translations from Latin, as well as Juda's mystical yet intellectual reading of the philosophy of Maimonides. At the same time, Moses shows himself to be a critical disciple (or reader?) of Juda of Rome, mentioning the Agent Intellect only once (unlike Juda), and providing a critical note on Juda's Sefer ben porat ('Book of the Fruitful Son', a commentary on Maimonides). The most important writing Moses acquired through the translation from Latin by Juda of Rome is the Liber de causis, prominent in Moses's writings, which stress the omnipresence of divine causality in the created world. Additionally, the Theoremata de esse et essentia of Giles of Rome, and Thomas Aquinas's commentary on the Liber de causis, seem to have reached Moses through Juda's translation. Beyond these writings, Moses's other sources are Aristotle, Maimonides, and the Hebrew Bible together with the Talmud. This combination of sources creates an interesting mix between Neoplatonic thought, the Aristotelian prevalence of actuality over potentiality, and Jewish mystical and philosophical ideas.

Rothschild seems to focus primarily on the influence of Juda of Rome's writings on Moses's thinking, since Moses acquired most of his sources through the translations of Juda of Rome, of which the Liber de causis seems to be the most important. Rothschild comments:

Moïse ben Sabbataï semble avoir cru trouver dans le Livre des causes sinon une démonstration, du moins une autorité philosophique en faveur de la thèse de la création a parte ante. [...] Le Livre des causes serait donc pour lui le témoin décisif de la 'philosophie véritable'.

Whereas Maimonides holds that neither the creation ex nihilo, nor the eternity of the world can be demonstrated, Moses seems to find in the Liber de causis the 'true philosophy' which does not only provide philosophical arguments in favor of an eternal creation a parte ante, but also arguments against currents of Jewish mysticism, philosophy, and rationalism. Rothschild names two other sources of Moses's thinking beyond Latin philosophy: traditional religious sources and the

3 Rothschild refers to Giuseppe Sermoneta, who provides a sketch of a Jewish philosophical 'school' in Rome at the end of the thirteenth century which joins Neoplatonic themes to Latin scholasticism, and is rooted in a strong adherence to Maïmonides. Sermoneta determines their main characteristic to be faith in the union of the human intellect with the Agent Intellect ( la fede nella possiblità d'unione tra intelletto possible e Intelletto Agente era divenuto il credo per così dire - 'ufficiale' die quella piccolo scuola di filosofie ebrei »). See GiUSEPPE SERMONETA, "La dottrina dell'intelletto e la 'fede filosofica' di Jehudah e Immanuel Romano », in Studi medievali, 6/2 (1965), p. 3-78, at p. 72.

4 Rothschild, Moise b. Sabbatai, p. 31. 
Kabbalah. It is most probable that the Kabbalistic doctrines were not unknown to Moses, as certain aspects of his writing are reminiscent of Menahem of Recanati, just as the title Ša'arēy ședeq ('Gates of Justice') could implicitly refer to Kabbalistic writings under the same title. Discussing Moses's traditional religious sources, Rothschild rightly accentuates Moses's knowledge of the Hebrew Bible, as well as aspects of Jewish liturgy. Rothschild attributes lesser importance to the Talmud in Moses's thinking, stating:

Quant au savoir talmudique mis en œuvre, il est extrêmement léger et limité au traité michnique des Pirqēy Avot (Chapitres des Pères [ou: des Principes]) et à quelques aggadot, anecdotes morales ou maximes lapidaires, parmi les plus célèbres. Moïse $b$. Sabbataï ne s'aventure qu'une fois à expliquer un passage talmudique, et il s'y montre assez peu compétent; il avoue d'ailleurs son peu d'estime pour la valeur spéculative du Talmud. ${ }^{5}$

I believe Moses was perhaps more acquainted with the Talmud than his writings portray at first sight. Moses believes that the Talmud, both in the halakhōt (legislative parts) as the aggadōt (narrative parts), does not lead to true wisdom. Nonetheless, it should be said that for Moses, Talmud as well as Scripture, could form a shared understanding with his adversaries, the Kabbalists. Therefore, Moses's Talmudic excursion in his explanation of the Psalm 119:126 should perhaps not be seen as "peu competent », but involves a careful re-reading of a shared source with the Kabbalists, in which Moses, using Kabbalistic vocabulary, subtly tries to win over his most-critical readers. This point will be explained more in detail below.

Three strains (Jewish mysticism, Aristotelian and Neo-Platonic philosophy, and Scripture) provide Moses with the intuition that God acts without any intermediary, and that creation is unique, a parte ante. Moreover, Moses underlines (through Maimonides's philosophy and the Plotinian influence on Liber de causis ${ }^{6}$ the assertion of negative theology that God cannot be known, except through his creation. This latter idea regarding the unknowability of God belongs to the core ideas that Moses adopts from his sources. This argument combines the Maimonidean negative theology, positing that God is transcendent and unknowable, with the (also Maimonidean) idea that God can be known only through creation. In its core, Moses's argument is heavily indebted to Aristotle,

Ibid., p. 28.

6 Rothschild refers here to the detailed study of Cristina D'Ancona Costa, who describes in more detail the Plotinian, monotheistic influence on Proclus's account. Doing so, she highlights the importance of negative theology of the Liber de causis, thanks to the Plotinian modification made to the doctrine of Proclus, which was unacceptable in a monotheistic regime. See CRISTINA D’Ancona Costa, Recherches sur le Liber de causis, Vrin, Paris 1995 (Études de philosophie médiévale). 
as it departs from the idea that the intellect, the intelligible, and the intellectual act are one. Since they are one, to Moses, it is precisely through the study of creation - which is understood to be the thought of the unique God - that one can access God to a certain extent. Rothschild, building on this double-edged argument, characterizes Moses's philosophy as

'mysticante', en tant que marquée au sceau d'une expérience personnelle de la divinité et formulée en des termes qui en témoignent, 'mystique' pouvant être nommé le niveau auquel parvient le disciple des philosophes à force de méditer sur les idées de l'unicité, de l'unité et de la transcendance absolues, ainsi que de la grandeur et de la beauté des œuvres, du Créateur. ${ }^{7}$

Whereas the Liber de causis provides Moses arguments in favor of a creation a parte ante, it is Aristotle and especially Maimonides, as well as notes of Jewish mysticism, that offer Moses the tools to think at once about the transcendence and the tangible presence of God.

Strikingly, those very same intellectual currents (i.e. Jewish mysticism, Latin philosophy, the Bible and Talmud) which constitute and offer to Moses his sources, at the same time also present theses Moses will harshly oppose. Rothschild writes:

Le Ša'arēy ședeq montre en Moïse b. Sabbataï un farouche adversaire, et pas mal informé des Kabbalistes, mais il ne se déclare pas moins éloigné du parti dit des Philosophes qui soutient l'éternité du monde, en dépit de l'enseignement révélé. Il combat encore les anti-intellectualistes qui bornent les devoirs - et les droits - de l'intelligence à la compréhension des préceptes de la Loi en vue de leur application. ${ }^{8}$

Moses thus is critical of three major groups - (1) Kabbalists, (2) philosophers, (3) halakists) - with whom he nonetheless shares many ideas.

\section{Moses and His Sources: A Critical Follower}

The first group Moses opposes are the Kabbalists. The Italian Kabbalists disciples of Abulafia and the 'recent' Italian Kabbalist, Menahem of Recanati (c. 1250-1310) - share with Moses the notion of 'effusion', and the opposition to the Platonic Ideas. Moreover, the Kabbalists share with Moses metaphors and formulas of this effusion, of the first cause and of the special status of the first created entities. Moses, however, will refute the Kabbalist conception of the sefirot (emanations) - a conception shared by both the ancient and recent threads

RoTHSCHILD, Moise b. Sabbatai, p. 38.

8 Ibid., p. 26. 
of Kabbalah - relying especially on the Liber de causis. Rothschild cites Recanati, thus presenting clearly the position Moses will criticize:

Toutes les choses d'en bas dépendent de choses plus élevées, car nous devons croire que les œuvres de Dieu sont exemptes de toute perfection; or ce monde dans lequel nous nous trouvons, nous voyons que tout [y] est passager. Il faut donc savoir que ce n'est pas [là] le premier existant qui procède de Dieu, car [si c'était le cas] la perfection de l'œuvre indiquerait celle de l'Artisan. Il nous faut donc dire que d'autres choses ont précédé, immuables, par l'intermédiaire desquelles est advenu le monde d'en bas. Et, à partir de celui-ci, nous [pouvons] connaître le secret du régime du monde d'en haut et les choses que l'on a nommées sefirot, etc. ${ }^{9}$

Menahem of Recanati speaks of a mediated creation, through the sefirot. He believes the notion of intermediate emanations having causality is necessary to safeguard God from the imperfections of the world, which are in his view caused by the intermediary causes and not by God himself. Moses, on the other hand, will argue strongly against this in his Ša'arēy ședeq, trapping the Kabbalists by posing a dilemma:

soit les sefirot sont en Dieu (selon les 'Kabbalistes anciens') et elles introduisent en lui une multiplicité inacceptable; soit elles sont en dehors de lui (pour les 'Kabbalistes récents') et tous les écrits de Moïse b. Sabbataï témoignent de son intuition fondamentale, contraire à toute idée de création par intermédiaire. ${ }^{10}$

To combat both the 'recent' and 'ancient' Kabbalists, Moses utilizes both Aristotelian and Neoplatonic conceptual tools - viz., the act-potency distinction of Aristotle and the Neoplatonic pair of the simple and composite, both of which underline the causal priority of the first principle, and its pure being with a creating causality. The Liber de causis and Aristotle's Metaphysics appear especially important here.

In Moses's explication of Psalm 119:126, where Moses argues against the interpretation of these Psalms as indicating that God operates 'in a moment', he makes strong use of the Liber de causis to show that God acts without intermediary, and can therefore not act through time. Moses writes:

Dieu agit par son existence seulement, sans avoir besoin de quelque chose de conjoint ou de quelque instrument qui serve d'intermédiaire entre lui et ses œuvres. S'il en est ainsi, il n'agit pas par l'intermédiaire du temps. Et si certaines

9 Menahem of Recanati, Ta'amey ha-mișwot, (Raison des commandements), ed. Isaac \& Eliézer Soncino, Constantinople 1544, [5]304 [1533/4], n.p., [p. 3], translated by RoTHsCHILD in Moise b. Sabbatai, p. 13-14.

10 RothschiLd, Moise b. Sabbatai, p. 14. 
des causes dernières ont besoin d'une continuité temporelle dans leurs actions, cela ne convient pas à la définition de Dieu. ${ }^{11}$

Departing from the Liber de causis (more specifically, proposition 19), Moses argues that God, acting solely by his existence, cannot act through intermediaries. ${ }^{12}$ The Aristotelian idea of the first principle that is pure act is also an important stepping stone in Moses's argumentation. Even though Moses is arguing here against the claim that God acts through the intermediary of time (and not arguing explicitly against the Kabbalists), he perhaps already points subtly to the sefirot, stating that other " dernières » causes cannot belong to God, as they would imply that God depends on something exterior, conditioned by time.

The true refutation of the Kabbalists appears in Moses's Ša'arêy ședeq. Moses writes:

Soit Dieu agit sans intermédiaire, soit au moyen d'intermédiaires extérieurs à sa substance. Si sans intermédiaire, alors l'opinion des philosophes selon laquelle les causés sont causes les uns des autres et celle des tenants des sefirot qui les considèrent comme les intermédiaires de la création sont fausses car s'il n'agit que par son désir et sa volonté, parce qu'en lui le désir, la volonté, l'unité et l'existence sont une seule substance, alors ces intermédiaires ne serviraient à rien. ${ }^{13}$

Moses argues here that if God is one, he does not need external sefirot, because he acts through his desire and will which both are one with his unique existence (cf. Liber de causis, where the first principle is «agens quod agit per esse suum tantum » [prop. 19]). Accordingly, the intermediate sefirot are unnecessary; but nothing in life exists without a reason; therefore, the sefirot do not exist. In sum, Moses argues that the sefirot - conceiving of them to be outside of God (i.e. the claim of the 'recent' Kabbalists) - cannot exist as absolute causes since everything flows from God, and God, as the first cause, transcends all other causality and does not depend upon it. What is more, stating that these sefirot are within God (i.e. the opinion of the 'ancient' Kabbalists) would be erroneous as well, since this would mean that God is composite and not simple, which is impossible since he is pure being.

11 Ibid., p. 53.

12 Liber de causis / Das Buch von den Ursachen: Lateinisch-Deutsch, prop. 19, 58, ed. and trans. ANDREAS SCHÖNFELD, Felix Meiner Verlag, Hamburg 2003 (Philosophische Bibliothek, 553), p. 40 «inter omne agens quod agit per esse suum tantum et inter factum suum non est continuator neque res alia media. et non est continuator inter agens et factum nisi additio super esse scilicet quando agens et factum sunt per instrumentum et non facit per esse suum <...> et sunt composita ».

13 Rothschild, Moise b. Sabbatai, p. 252. 
Strikingly, with these same arguments, Moses will go against his (probable) master, Juda of Rome. In Juda's Ben porat, as a commentary on the words that the first cause makes existing every existent, we read: "il fait exister en qualité d'agent qui a deux actions. Car tous ses effets sont [produits] au moyen d'intermédiaires » (p. 228). Juda of Rome limits here the actions of the first cause strictly to the First Intellect, which in turn imparts a series of intermediary causes. Moses, with the help of Isa 48:13, reuses his argument against the Kabbalists, this time addressed at his master (?) Juda of Rome, and states « [Dieu] n'a pas besoin d'intermédiaire entre lui et les creatures » (p. 229). Accordingly, Moses both is a patient reader of Juda of Rome and at the same time critical of his master.

The second group Moses criticizes are the philosophers who argue against the eternity of the world. These philosophers either argue (1) that the world is not eternal because it was created by God and thus has a starting point, or else they argue (2) that the eternity of the world is a parte post, an eternity conditioned by the moment of creation. Moses will use the Liber de causis to argue, instead, that the eternity of the world is created by God and that this eternity exists a parte ante. With this group of philosophers, Moses does share the idea of a created world and similarly is in need of a philosophical system to think about God's eternity in relation to this created world. Moses's first discussion related to the idea of an eternal world appears in his explication of Psalm 119:126. Here, Moses argues against those who think that the six days of creation point to God's acting through time. However, since God does not act through an intermediary (i.e. neither through time), it is impossible that God's creation took place within time. It is not God who created the world through the intermediary of time, but rather the inverse: «Le temps, avec toutes ses parties, est créé par l'intermédiaire de l'existence une, créée, et non l'inverse, car le temps est un accident inhérent au mouvement de la sphère et est une partie accidentelle des accidents créés " (p. 64) Again, the combination of Aristotle and the Liber de causis is here apparent. Moses uses the Liber de causis to assert that God's creation preceded eternity, as we read in proposition 4 [37] (" prima rerum creatarum est esse et non est ante ipsum creatum aliud») and proposition 2 [24] ("causa prima est supra aeternitatem quoniam aeternitas est causatum ipsius $»)$. Besides this eternity $a$ parte ante, Moses refers to the Aristotelian system of spheres, of which time is an accident. Rothschild summarizes the argument sharply:

Dieu, son acte créateur, son attention au monde qu'il a créé [...] ne sont pas soumis au temps [...] l'ensemble de la création procède d'un acte unique et instantané ou plutôt précédant le temps, en dépit des divisions du créé (auxquelles correspondent les 'jours' du récit de la création. ${ }^{14}$

$14 \quad$ Ibid., p. 49. 
The theme of eternity a parte ante returns in the other writings of Moses. In his Ša'arey sedeq, Moses does not speak explicitly of the theme of the world's eternity, but makes reference to it by comparing creation to a bouquet of myrrh (an image from Song of Songs):

l'intelligible suprême [...] a été comparé à un bouquet de myrrhe car, de même que le parfum de celle-ci monte de manière égale, sans qu'une partie soit cause ou causée l'une de l'autre, de même les formes séparées incluses et intelligées par le 'bien-aimé', intelligible suprême ne sont point causes ou causées l'une de l'autre, mais sont épanchées et créés par l'épanchement suprême, pur et intact, duquel sont épanchés toute existence, tout bien et toute perfection..$^{15}$

Moses is speaking here of God in terms of the supreme intelligible, and accordingly, the context in which the theme of creation is treated differs from the one in Explication of Psalm 119:126. Moses here stresses - similar to his argument against the Kabbalists - that creation takes place as a pure effusion, without intermediary causes or tools. Again, Moses seems to be inspired by the Liber de causis:

La thèse célèbre de la prop. 1 du Livre des causes semble, ici et dans le paragraphe suivant, implicitement présente, mais poussée à la limite: la cause première est agissante dans les causes secondes et plus forte qu'elles, au point qu'elle est en vérité la seule cause, même si les causés sont attachés les uns aux autres. ${ }^{16}$

What is more, Moses introduces here a special kind of causality, that characterizes the creative causality of God. Rothschild speaks of « une causalité [créatrice] en-deça de la causalité [relative, ou apparente] des causes agissantes dans le monde qui est déployé dans l'exégèse du 'bouquet de myrrhe' » (p. 239). It is exactly this type of causality that will allow Moses to argue against Thomas Aquinas's conception of the eternity of the world, in his note on Thomas's commentary on the Liber de causis (translated by Juda of Rome). Moses argues that when philosophers like Aquinas state that the world is not created in time, they defy the Torah. For Moses, the world is not eternal, but the creation of it precedes time. Here again, he makes use of the Liber de causis, stating:

c'est Dieu qui épanche tous les existants, l'existence éternelle et l'existence matérielle, comme y fait allusion l'auteur du Livre des causes, dans la proposition 2

15 RothschiLd, Moise b. Sabbatai, p. 125.

16 Ibid., p. 126, fn. 132. 
en disant: 'l'existence qui est au-dessus de l'éternité est la Cause première, car elle est sa cause'..$^{17}$

Similar to the "causalité en-deça de la causalité », Moses has in mind "une antériorité [de la création] en-deça de la temporalité » (p. 239). The world is thus not eternal, for eternity belongs only to God, but it is eternal a parte post, imputed on the world by the First Cause.

The third group Moses combats are the halakists. These Jews study the Torah and Talmud only for practical and legal purposes, but not as a means for intellectual or theoretical speculation. With this group, Moses shares a real reverence for the Law and the Talmud, which he uses on multiple occasions both as arguments from faith, as well as for offering exemplary metaphors. Moses's disagreement with this group stems from his (almost Averroïst) stance that the human intellective soul should approach, as much as possible, the supreme intelligible - viz., God. That people are occupied only with material or practical matters constitutes a huge obstacle in reaching that goal and, ultimately, attaining human perfection. In these matters, Moses is strongly inspired by Maimonides's negative theology, which implies that God is unknowable except by His effects. This is why Moses, in his Ša'arēy ședeq, uses the image of the Artisan: "On ne peut louer un artisan pour son acte à moins de connaitre celui-ci. Par la connaissance des œuvres de Dieu nous pourrons à la fois le louer quant à celles-ci et aussi atteindre les concepts métaphysiques relatifs à lui »(p. 107). Arriving at knowledge of the created world is like knowing the arts of the artisan - viz., God. Obtaining this knowledge has a twofold importance. First, it helps the human (intellective) soul to achieve its perfection. Indeed, in the beginning, the human soul is essence in potency, which contains in potency the six kinds of 'arts' of God (material existence, the spheres and stars, intellective human soul, heavenly intellective soul, angels/separated intellects, archangels, and the first intellect). Contained potentially in the soul, the human soul can activate this knowledge through science and reach God, who is both its perfection and its eternal and immovable source. Accordingly, the perfected human soul knows its own Artisan. Secondly, this knowledge has as a consequence the fact that man will exalt God with respect to his arts: man will be able to exalt God fully, as he knows all of God's arts. The importance of this intellective activity is already apparent in Moses's explication of Psalm 119:126, where Moses explores the other side of his argument, explaining why it is harmful to be absorbed in practical or material matters, rather than pursuing intellectual affairs. He states: "l'âme humaine étant unifiée en ses capacités [diverses], tant qu'elle est absorbée dans l'activité de l'une, elle est empêchée de se prodiguer dans l'activité de l'autre »(p. 67). Man

17 Ibid., p. 240. 
is quite far from arriving at knowledge of God and the other intelligibles while overly absorbed by material and practical concerns. This is why, for Moses, the liturgical time is so important: these days offer man time away from practical matters, in order to invest in acquiring knowledge of intelligible objects in order to attain perfection. Perhaps the major mistake of the halakists is not so much that they focus on the legal and practical aspects of the sacred scriptures, but that they find in these laws an end in themselves. Moses, on the contrary, conceives of the Law as a way for the human intellective soul to attain perfection: «La sainte Loi nous a prescrit de faire certaines actions qui incitent l'âme à se faire des représentations intellectuelles au moyen desquelles elle passe de la puissance et de la virtualité à l'acte et la perfection » (p. 63). Following the Law should not be seen as an end, but rather as a way of attaining perfection.

\section{Attaining Knowledge: Return by Waking-up}

In a recent article, Rothschild accentuates the importance of linguistic phraseology in Moses's writings: «l'hébreu de Moïse b. Sabbataï laisse transparaître des tournures et des constructions manifestement calquées sur l'idiome vernaculaire $\gg .^{18}$ This is a common characteristic of many texts and translations of the end of the thirteenth to the middle of the fourteenth century, and much research has been done on this specificity in Hebrew, Latin, and dialects. ${ }^{19}$ An interesting question to answer, in the light of Rothschild's book, would be to know whether there was a specific philosophical vocabulary of the so-called Italian Jewish Maimonidean 'cult' or 'school' that existed during that period. Rothschild's glossary of Moses's vocabulary forms an exceptional tool and provides an avenue towards answering this question. One of the Hebrew twists, not so much related to the vernacular idiom, but important to Moses's writing, is his epistemological description of the human intellective soul proceeding from potency to act in terms of 'waking up' and 'repentance'. In Moses's explication of Psalm 119:126, Moses b. Sabbataii speaks of the need to turn away from material occupations, towards intellectual activities in order to know all the created world in order to reach God, and subsequently human perfection. In paragraph 5 of Moses's Psalm-explication, he builds to his subsequent explanation of Isa 55:6 (« Seek God while he may be found; call on him while he is near »). In fact, Isa 55:6 as interpreted in the Talmud could serve as an objection against Moses's

18 JeAn-Pierre Rothschild, "Langue et littérature hébraïques dans l'Occident médiéval et moderne ", Annuaire de l'École pratique des hautes études (EPHE), Section des sciences historiques et philologiques, 150 (2019), p. 33-37, at p. 37.

19 See for instance MAURo ZonTA, Hebrew Scholasticism in the Fifteenth Century: A History and Source Book, Drodrecht, Springer 2006. Also the $22^{\text {nd }}$ issue of Yod treats the extensive vocabulary in (amongst others) Renaissance Italy: Alessandro GuetTA, DiAna Di SEGni (eds.), Medieval and Early Modern Translations of Maimonides' Guide of the Perplexed, in Yod, 22 (2019). 
argument that God does not act through time. A sage of the Talmud would have interpreted this verse as pointing to the specific days between New Year and Yom Kippur as the days in which prayers are heard. This would imply that God sometimes listens and sometimes does not, which, in turn, implies that God would act through the intermediary of time. Already preparing the refutation of this Talmudic interpretation (the only Talmud-paragraph Moses cites in his works), Moses, in the preceding paragraph 5, argues that the liturgical time is not installed for God to either act or not act, but is there to free man from worldly occupations. Accordingly, we read:

la Loi [...] leur avait spécifié des jours connus et des temps fixes parmi les jours de l'année afin qu'ils s'y réparassent des vanités du temps et des préoccupations du corps et de ses plaisirs, s'y éveillassent de leur sommeil et s'y repentissent d'un entier repentir en se rappelant le caractère du créé du monde [...] pendant qu'ils gravent dans leur représentation et leur connaissance ce qu'ils peuvent atteindre de l'existence de Dieu. ${ }^{20}$

The Law fixes liturgical moments in order to free man from material occupation, for him to attain knowledge. This abstinence from material or practical activities and movement towards intellectual occupation is described in terms of waking up and, even more surprising, repentance. The Hebrew used here reads: וישובו " (And they repented within [these fixed days] with a complete repentance »).

The use of repentance is surprising here, even more so because later in the same passage, the same metaphor of awaking from sleep is used (p. 66), while the image of repentance does not return.

The image of waking up fits well with the Aristotelian epistemology we have encountered in Moses's writings, describing how, at first, the human intellective soul contains the intellective forms in potency and then moves to possess these in act, and thus attains its perfection. Moses writes:

l'âme intellective humaine, étant informée de la part de l'existence divine [...] aussitôt cette âme [intellective] est éveillée de son sommeil et se prend de dégoût pour les vanités et les plaisirs du monde; il se crée en elle un désir et un amour intellectuels pour le seul service de Dieu. ${ }^{21}$

Here again, Moses describes the acquisition of the human intellective soul's knowledge of God in terms of 'waking up' from the material world, in order to follow the spiritual and moral path of truth that leads to God. Perhaps this notion

20 RothschiLd, Moise b. Sabbatai, p. 66.

21 Ibid., p. 72. 
of waking up is necessary for Moses to show that it is not so much that the created world causes man to attain God, since this would introduce the created world as an intermediary cause, but rather that these divine truths are already present within man (even if only in potency at first), stemming from God and leading to God. Besides, the metaphor of waking up, could provide Moses with the tool to allow a theodicy for God. Indeed, when Juda of Rome writes in his Sefer ben porat that the causality of the First Cause is limited to the first of the superior existents, he exempts God from the imperfections of the world, which are attributed to secondary, intermediary causes. Moses, in his strong opposition to God requiring intermediary causes, does not provide this 'alibi' for God. Rothschild comments:

La différence entre ces deux types d'explication, c'est d'abord que le premier, celui de Juda de Rome, résout le scandale de l'injustice en relativisant en termes d'économie interne du monde et de rapport du tout et de ses parties, alors que le second, celui de Moïse b. Sabbataï, relativise l'importance de la vie dans ce monde. ${ }^{22}$

Moses, stressing the intellective, rather than material (and therefore imperfect and unjust) life, tries in his way to safeguard God from earthly imperfections that would appear in the metaphor of 'waking up' as only a bad dream.

Accordingly, the metaphor of 'waking up' does not come as a surprise and can be explained from different angles. But what about 'repentance'? In order to understand what repentance has to do with acquiring knowledge, we ought to look at the Hebrew. The Hebrew uses the word teshuva (תשובה), which can indeed be translated as repentance. Its meaning can be traced back to the root 'shuv' (שוב, to turn), equivalent to 'niham' (נחם, to repent, to console), pointing at a dynamic form of repentance. ${ }^{23}$ Teshuva can also be understood in a broader way as returning. ${ }^{24}$ It could be interesting to posit that in the above-cited passage we find an instance of ambiguity as well as precision in which Moses employs both understandings of teshuva at once. Understanding teshuva in its broader sense as return, one could read the phrase from the same Aristotelian perspective as 'waking up'. When man attains knowledge, especially knowledge of the First Principle, the human intellective soul returns to what it already contained in potency, but now possesses in act. Doing so, man acknowledges God as his perfection and as his source. Thereupon, man exalts God, which could be seen as

$22 \quad$ Ibid., p. 229.

23 Kohler Kaufmann, Max Schlesinger, « Repentance (Hebr. 'teshubah') », in Jewish Encyclopedia, ed. ISIDORE SINGER, Funk and Wagnalls, New York 1906, p. 376-379.

24 Louis E. Newman, Repentance: the Meaning and Practice of Teshuva, Jewish Lights Publishing, Vermont 2010, p. 107. 
an ultimate return to its eternal and immovable source. Next to understanding teshuva in its broad sense, its moral meaning as 'repentance' is crucial in understanding the context of the passage. We find Moses's reference to teshuva under the title, "Raison du calendrier liturgique ». Moses previously argued that God does not act through time, since He acts without intermediary. This raises the question regarding the necessity of the liturgical calendar: if God does not act through time, why would liturgical time be necessary? Moses argues that we need this time to reach God, by turning away from corporeal activities during liturgical feasts. He stresses in particular the importance of Yom Kippur. In the preceding part of the text, Moses writes:

Tous ces jours sont-ils réservés à éveiller notre intellect de la torpeur du sommeil et à [lui] faire acquérir le monde futur. De même pendant les dix jours qui sont entre le Jour de l'An et Kippour, Dieu nous a ordonné de nous consacrer pendant ce temps, par les prières et implorations, et de revenir d'un entier repentir, et de nous mortifier le jour de Kippour [...] pour inciter notre intellect à revenir à lui d'un repentir complet. ${ }^{25}$

We should first note the twofold combination of the terms 'return' (שוב in the Hebrew text) and 'repentance' (תשובה). The two senses of teshuva seem to be interwoven here. Moreover, the image of 'waking up' is also used here. There seems to be a strict correlation between attaining knowledge by waking up from worldly pleasures and returning to God by repenting. These two interwoven motifs stress the importance of liturgical time, not as an intermediary of God, but as an intermediary of man to come to God. The repentance that takes place on Yom Kippur, accordingly, seems to have not only moral, but also epistemological implications. By confessing one's sins before God, man 'wakes up' from worldly pleasures and vows to follow God's path, thereby searching to know God by acquiring the six intelligible forms that he already possess in potency, and ultimately perfecting the human intellective soul.

The combination of the metaphor of 'waking up' together with 'repentance' can perhaps be seen as a limitation on the rationalist undercurrent of Moses's ideology. Whereas Moses had argued against the halakists, claiming that they are too concerned with practical matters at the expense of pursuing speculative and theoretical truth, perhaps Moses argues here the inverse: man cannot place his trust upon the intellect alone; the practical, liturgical matters are also important in reaching God. Man has to 'wake up' from his corporeal pleasures and devote himself to the search of God, and at the same time the practical, liturgical rituals will both enflame and sustain his desire to know God. The two images (waking up and repenting) appear here as different perspectives on man. Man awakening is

25 RothschiLd, Moise b. Sabbatai, p. 65. 
the human intellective soul fervently seeking God, as independent as possible from practical matters. Man repenting is man dependent upon practical matters, but more importantly, man dependent upon divine grace. This double face of man, of dependence and independence, is visible most clearly in Moses's poem Šir 'eden ha-hayyim (Song of the Eden of the living). This poem consists of a chorus and four stanzas. In the second strophe, we read: "Discerne [les voies de] la recherche de l'intellect et tu acquerras la félicité des vivants» (p. 247). This phrase points to the importance of the perfection of the human intellective soul by acquiring knowledge of the intellectual forms. In the fourth stanza, we read: "J'écouterai la voix qui me réveille: 'Lève-toi, somnolent, écoute les paroles plus que l'or, l'or fin, précieuses et tu verras la voie des vivants'» (p. 248). In the fourth stanza, the image of waking up returns. Moses portrays man here as drowsy and fatigued, desperate for help. It is God's voice who will awaken the man in need, and who will lead him to the way of the living. Similar to Yom Kippur, where man confesses his sins and waits for a divine response, here man waits for God's voice to wake him up. Rothschild comments on the poem:

L'étude scientifique de la création, celle-ci ne peut servir que de 'promesse' ou de 'confirmation'; mais on ne saurait s'engager sur la Voie elle-même sans un appel divin (strophe 4): n'est-ce pas là, tout de même, introduire comme la notion d'une grâce divine en forte réaction contre le naturalisme intellectualiste maïmonidien selon son interprétation rationaliste classique, d'après laquelle la mise en œuvre des facultés et du programme intellectuels requis entraîne infailliblement l'adhésion à l'Intellect Agent? Et même, une mise en doute du rôle de l'intelligence tel que l'a conçu Juda de Rome?26

Rothschild views the last stanza in light of the criticism of the over-independent, infallible (human) intellect. Perhaps Moses does not have in mind specifically Maimonides, nor Juda of Rome. Nonetheless, his criticism on an overly categorical rationalism by his emphasis on divine grace through the need of God's voice and the emphasis on repentance that requires a divine answer, seems to fit Moses's general ideology. Indeed, Moses, from the beginning, stresses the dependence of everything upon the First Cause. In this view, mankind does not form an exception: even though the human soul can independently acquire knowledge through science and thus climb up to know the first principle, he still depends upon God who will wake him up, forgive him, and place him on the track of acquiring truth.

The use of the interwoven images of 'waking up' and 'repentance' is not only characteristic for Moses's thinking, but fits also into what Rothschild

26 Rothschild, Moise b. Sabbatai, p. 249. 
characterizes as the 'performative writing' of Moses b. Sabbatai. Rothschild explains:

Ne suivant pas [...] les règles de la logique aristotélicienne et reproduisant en quelque sorte le flux métaphysique qu'il décrit, il peut être regardé [...] comme pratiquant une sorte d'écriture performative dans laquelle le flux de l'écriture traduit, voire suscite, celui de la pensée elle-même [...] et doit entraîner à son tour non la conviction (argumentative), ni la persuasion (rhétorique), mais l'élévation de l'âme du lecteur qui lui permet de parvenir à la coïncidence de l'intelligent, de l'acte d'intellection et de l'intelligible. ${ }^{27}$

In this performative writing, the writing itself carries the reader very subtly to the conclusion and it forms the way to understanding (rather than representing the result of understanding). It is precisely within the framework of this 'nudging,' performative writing that we should situate Moses's use of the term teshuva (repentance). First of all, we find this term in a paragraph that prepares the re-reading of a Talmudic interpretation of Isa. 55:6 (" Seek God while He can be found, Call to Him while He is near »). This Talmudic interpretation was probably known to the Kabbalists. Menahem of Recanati, whom we cited earlier amongst the 'recent' Kabbalists of Moses's time, shows in his interpretation of this verse striking similarities to the Talmudic interpretation of the verse as God acting through the intermediary of time. Recanati, in his commentary on the Torah, draws the parallel between Isa 55:6 and the story of Abraham and Isaak. ${ }^{28}$ Recanati sees the invocation of the name of Abraham, when he is about to sacrifice his son, as a "gate (Ša'ar) to Bina (understanding) and Teshuva (repentance) ». He then draws attention to the verse of Isa 55:6, and states that God is being near, and can thus be invoked, when these so-called 'gates' are open, and the path to God is not far. This brings us to a second point of Moses's subtle argumentation. Moses uses the term teshuva (repentance). This term is far from being neutral. Instead, its use is strongly related to the Kabbalistic doctrine of the sefirot, ${ }^{29}$ where teshuva figures mostly amongst the highest sefira of Bina (understanding).${ }^{30}$ Even more important to note is that the term teshuva was used

Ibid., p. 38.

Menahem of Recanati, Vayera, p. 24.

29 BRIAN OGREN, The Beginning of the World in Renaissance Jewish Thought: Ma'aseh Bereshit in Italian Jewish Philosophy and Kabbalah 1492-1535, Brill, Leiden 2016 (Supplements to The Journal of Jewish Thought and Philsophy, 27), p. 124: «In Kabbalistic parlance, Teshuvah is a common designation for the third sefirah of Binah as the upper Teshuvah, and for the tenth sefirah of Malkhut as the lower Teshuvah".

30 At least two important Kabbalistic writings associate teshuva with bina: RABBI IsAAC, Perush le-Sefer Yetzirah, 15, line 333; RABBI Asher B. DAVID, Kabbalat, 18, 1.40. Cited in MARK Verman, The Books of Contemplation: Medieval Jewish Mystical Sources, State University of New York Press, New York 1992. 
explicitly in connection with these sefirot in the writings of Menahem of Recanati. Rothschild states that it is possible that Moses knew this recent Kabbalist (p. 13) and it is very probable that Moses's polemics against the recent Kabbalists were addressed (at least partly) at Menahem of Recanati. Recanati explicitly connects teshuva to the sefirot of Bina (understanding) and Malkhut (kingdom) ${ }^{31}$ In this light, it could be possible to read Moses's use of teshuva as a subtle criticism on the Kabbalists. By using a term so dear to the Kabbalists in his metaphysics in order precisely to oppose Kabbalistic ideas, Moses turns the weapons of the Kabbalists against them.

\section{Conclusion}

In conclusion, the nuanced, well-researched and extremely detailed study of Moses $b$. Sabbatai proves to be an interesting starting point for further studies on Jewish philosophy at the end of the thirteenth and beginning of the fourteenth century, which up to now «figure à peine dans la cartographie ou la chronologie de l'histoire de la pensée juive» (p. 1). Rothschild makes clear that Moses b. Sabbatai offers a valuable window into this still under-studied period - « a gap in the history of Jewish thought between the late Middle Ages and the early Renaissance ${ }^{32}$ - and through his analysis of Moses's commentary on Aquinas highlights the interplay between Latin scholasticism and Jewish (Maimonidean) philosophy. As has been shown by Giuseppe Veltri in his recent book on the Renaissance in Jewish thinking, the under-studied role of Judaism in the mostly Christian Renaissance brings up important and uncovered elements of this admired period in history. ${ }^{33}$ Veltri rightly indicates that Judaism stood between inclusion and exclusion in the Renaissance, where it was not so much the homo universalis, but rather the homo christianus that was central. Nonetheless, because the Jews were in possession of the lingua sacra (Hebrew), which was revalued within the "return to the old» of the Renaissance, Judaism certainly had its place in the religious and intellectual exchange between Christians and Jews of the time, focusing on the Biblical sources and mysticism. Certainly, we can place Moses b. Sabbataï in this landscape, as it is clear how his combination of Biblical exegesis and mysticism forms a response not only to the Kabbalists, but also to Christian thinkers such as Thomas Aquinas. Rothschild, in a recent article,

31 Menahem of ReCanati, Nasso 2 (Commentary on Numbers, 17): בוא וראה אפילו כנסת ישראל שהיא מלכות מכרות נקראת תשובה ואם תאמר תשובה עליונה שהיא בינה היא אינה מצויה בכל מקום Translation by OgREN, The Beginning of the World, p. 124: "Come and see: even the Assembly of Israel, which is Malkhut, is called Teshuvah, and if you should say that it is the upper Teshuvah, which is Binah, [know] that this is not found in every place ».

32 See the review by ELISA CODA in Studia graeco-arabica, 9 (2019), p. 344.

33 Giuseppe Veltri, Il Rinascimento nel pensiero ebraico, Paideia, Turin 2020 (Biblioteca di Cultura Ebraica Italiana, 3). 
stresses one important aspect of this religious and intellectual exchange.$^{34} \mathrm{He}$ focuses on the interest for Christian literature among Jews in Italy, France, and Iberia in the fourteenth and fifteenth centuries. Even while no common language existed between Jews and Christians at the time, the intellectual exchange was possible thanks to Greco-Arabic sources shared by both the Jewish and Latin world. Moses b. Sabbataï is in this regard an excellent example of the intellectual exchange between Jews and Christians, as it becomes clear how the Liber de causis functions as a shared understanding between Latin scholasticism and Jewish philosophy, enabling thus an interchange that is not solely religious, but also deeply philosophical. Within this intellectual, philosophical exchange, we briefly touched upon the issue of the specific language and phraseology used in Jewish Italy, and focused on the image of 'waking up' and 'repentance.' In her article on Jewish-Italian, Sandra Debenedetti Stow more deeply analyzes certain linguistic aspects and lists works that portray the specific philosophical and religious language of Jewish Italy. ${ }^{35}$ It would be most interesting to integrate Moses $b$. Sabbataï into these studies, since his specific phraseology and philosophical vocabulary offer another outlook on Jewish-Italian in the fourteenth century. Questions that need to be answered include: Was there a specific vocabulary of this Jewish-Italian school? If so, what role does Moses b. Sabbataï play in this linguistic exchange? Does Moses share a specific language with this school, or does he keep to a rather standard language? In any case, it must be remarked that Rothschild's translations of Moses b. Sabbataii's works are both accurate and reliable: the critical apparatus with the text and the extensive glossary are indicative of a meticulous translation, most useful not only for future studies on Moses, but also the general Hebrew reception of the Liber de causis. In sum, Rothschild's book portrays a thinker who provides an insight into Judaism in the Renaissance, more specifically in Italy of the fourteenth century, and furnishes detailed and critical materials that might spark further studies on the exchange between Latin scholasticism and Judaism, and the specific language associated within this exchange.

34 JeAn-Pierre Rothschild, "Quelques philosophes juifs du Moyen Âge tardif, traducteurs ou lecteurs de saint Thomas d'Aquin », in Elias H. Füllenbach, Gianfranco Miletto (eds.), Dominicans and Jews: Personalities, Conflicts, and Perspectives from the 13th to the 20th Century, De Gruyter, Berlin 2014 (Quellen und Forschungen zur Geschichte des Dominikanerordens - Neue Folge, 14), p. 2564.

35 SAndRa Debenedetti Stow, «Il giudeo-italiano dal medioevo al primo Rinascimento: Caratteristiche, metodologia, studi e sviluppi », La Rassegna Mensile di Israel, 82/2-3, Umberto Cassuto: Maestro di Bibbia nel Paese della Bibbia, t. 1 (May-December 2016), p. 257-284. 